\title{
Miniaturized cardiopulmonary bypass improves short-term outcome in cardiac surgery: A meta-analysis of randomized controlled studies
}

\author{
Alberto Zangrillo, MD, ${ }^{\mathrm{a}}$ Francesco Alfredo Garozzo, MD, ${ }^{\mathrm{a}}$ Giuseppe Biondi-Zoccai, MD, ${ }^{\mathrm{b}}$ \\ Federico Pappalardo, MD, ${ }^{\mathrm{a}}$ Fabrizio Monaco, MD, ${ }^{\mathrm{a}}$ Martina Crivellari, MD, ${ }^{\mathrm{a}}$ Elena Bignami, MD, ${ }^{\mathrm{a}}$ \\ Massimiliano Nuzzi, MD, ${ }^{a}$ and Giovanni Landoni, MD $^{\mathrm{a}}$
}

\begin{abstract}
Objective: To investigate whether the use of miniaturized cardiopulmonary bypass translates into decreased morbidity and mortality in patients having cardiac surgery.

Methods: We independently conducted a systematic review and meta-analysis of data pooled from existing trials listed in PubMed and conference proceedings. Sixteen studies were identified, including 1619 patients having cardiac surgery. Inclusion criteria were random allocation to treatment and comparison of a miniaturized cardiopulmonary bypass system versus conventional cardiac surgery. Exclusion criteria were duplicate publications, nonhuman experimental studies, and no outcome data. The end points were the rate of neurologic and myocardial damage and the number of patients transfused.
\end{abstract}

Results: Miniaturized cardiopulmonary bypass was associated with significant reductions of neurologic damage $(4 / 548[0.7 \%]$ vs $19 / 555[3.4 \%]$, odds ratio $=0.30[0.12-0.73], P=.008)$, reduction in peak cardiac troponin (weighted mean difference $=-0.15 \mathrm{ng} / \mathrm{dL}[-0.18,-0.11], P<.001$ ), and in the number of transfused patients $(55 / 552[9.9 \%]$ vs $101 / 563[17.9 \%]$, odds ratio $=0.42[0.28-0.63], P<.001)$. No difference in mortality was noted $(8 / 758[1.0 \%]$ vs $14 / 771[1.8 \%]$, odds ratio $=0.60[0.26-1.39])$.

Conclusions: Miniaturized cardiopulmonary bypass has beneficial effects resulting in decreased transfusion rate and cardiac and neurologic damage. (J Thorac Cardiovasc Surg 2010;139:1162-9)

Cardiopulmonary bypass $(\mathrm{CPB})$ with aortic crossclamping and cardioplegic arrest remains the gold standard technique to perform cardiac surgery. It induces an inflammatory response (largely determined by the blood contact with foreign surface and the activation of the complement) and renal, pulmonary, and neurologic dysfunction. ${ }^{1,2}$ Coronary artery bypass grafting $(\mathrm{CABG})$ using $\mathrm{CPB}$ is still the most accepted technique to treat coronary artery disease. However, the morbidity attributed to CPB is still significant. ${ }^{3}$

The search for a less aggressive and more biocompatible $\mathrm{CPB}$ led to the use of miniaturized $\mathrm{CPB}$, based on the idea of a closed low prime volume circuit consisting of a rotary blood pump and a membrane oxygenator as the only components. The venous blood returns through active drainage. There is no venous reservoir and no cardiotomy suction device. It minimizes hemodilution and mechanical blood trauma. The shed blood is separated from the systemic circulation. The components, including the tubing, are heparin-coated. ${ }^{4,5}$

\footnotetext{
From the Department of Anesthesia and Intensive Care, ${ }^{a}$ Università Vita-Salute San Raffaele, Milan, Italy, and Interventional Cardiology, Division of Cardiology, ${ }^{\mathrm{b}}$ University of Turin, Turin, Italy.

Disclosures: None.

Received for publication Feb 4, 2009; revisions received June 19, 2009; accepted for publication July 16, 2009; available ahead of print Sept 23, 2009.

Address for reprints: Landoni Giovanni, MD, Department of Anesthesia and Intensive

Care, Istituto Scientifico San Raffaele, Via Olgettina 60 Milano, 20132 Italy

(E-mail: landoni.giovanni@hsr.it).

0022-5223/\$36.00

Copyright (c) 2010 by The American Association for Thoracic Surgery

doi:10.1016/j.jtcvs.2009.07.048
}

To address the question whether the use of miniaturized CPB might influence patients' outcome after cardiac surgery, we independently conducted a systematic review and meta-analysis of data pooled from existing trials to determine the impact of miniaturized CPB on the rate of transfusion and on cardiac and neurologic damage in patients having cardiac surgery.

\section{MATERIALS AND METHODS Search Strategy}

Pertinent studies were independently searched in PubMed (updated May 20, 2008) by 4 trained investigators. The full PubMed search strategy was developed according to Biondi-Zoccai and colleagies ${ }^{6}$ and is available in the appendix. Further hand or computerized searches involved the recent (2006-2008) conference proceedings from the International Anesthesia Research Society, European Association of Cardiothoracic Anaethesiologists, and European Association of Cardiothoracic Surgery congresses. In addition, we used backward snowballing (ie, scanning of references of retrieved articles and pertinent reviews) and contacted international experts for further studies. No language restriction was enforced and non-English-language articles were translated before further analysis. In the present study, miniaturized CPB was defined as a system with a low prime circuit and without a cardiotomy reservoir, in which venting lines are driven into the cell saver directly or into a vacuum bag reservoir. No blood-air contact was compounded in this system; shed blood separation was strictly followed. Conventional $\mathrm{CPB}$ was defined as what is routinely used in every routine cardiac surgery procedure: massive hemodilution, cardiotomy suction, blood-air contact.

\section{Study Selection \\ References obtained from database and literature searches were first in- dependently examined at the title/abstract level by 4 investigators with}




\section{Abbreviations and Acronyms}

$\begin{aligned} \mathrm{CABG}= & \text { coronary artery bypass grafting } \\ \mathrm{CPB}= & \text { cardiopulmonary bypass } \\ \mathrm{OR}= & \text { odds ratio } \\ \text { QUOROM = } & \text { The Cochrane Collaboration and } \\ & \text { the Quality of Reporting of } \\ & \text { Meta-Analyses } \\ \text { WMD }= & \text { weighted mean differences }\end{aligned}$

divergences resolved by consensus, and then, if potentially pertinent, retrieved as complete articles.

The following inclusion criteria were employed for potentially relevant studies: random allocation to treatment and comparison of a miniaturized CPB system versus a conventional cardiac surgery. Exclusion criteria were duplicate publications (in this case only the article reporting the longest follow-up was abstracted), nonhuman experimental studies, and lack of outcome data.

Two investigators independently assessed compliance to selection criteria and selected studies for the final analysis, with divergences finally resolved by consensus (Table 1).

\section{Data Abstraction and Study Characteristics}

Baseline, procedural, and outcome data were independently abstracted by 4 trained investigators with divergences resolved by consensus (Table 1 , Table 2). Specifically, we extracted study end points and main outcomes, study design (including patient selection, randomization, single-/multicenter design, open or single-/double-blind design), clinical setting, population, and adverse events.

The primary end point of the present review was the rate of blood transfusion and cardiac and neurologic outcome, and the coprimary end point was the rate of hospital mortality. Blood transfusion was defined as the number of patients receiving at least $1 \mathrm{U}$ of red blood cells during surgery or in the postoperative period. Cardiac damage was defined as an increase of the cardiac biomarker cardiac troponin I. Neurologic damage was defined as postoperative type 1 (focal neurologic complication) or type 2 (altered mental status) neurologic complication.

Other relevant secondary end points were time on mechanical ventilation, intensive care unit and hospital stay, atrial fibrillation, bleeding $(\mathrm{mL})$, surgical reexploration, myocardial infarction, intra-aortic balloon, low cardiac output syndrome, use of inotropic drugs. At least 2 separate attempts at contacting original authors were made in cases of missing data.

\section{Internal Validity and Risk of Bias Assessment}

The internal validity and risk of bias of included trials were appraised according to revised methods recommended by The Cochrane Collaboration methods (Table 3). Two independent reviewers appraised study quality, with divergences resolved by consensus.

\section{Data Analysis and Synthesis}

Computations were performed with SPSS 11.0 (SPSS, Chicago, Ill) and RevMan 4.2 (a freeware available from The Cochrane Collaboration). ${ }^{7}$ Statistical heterogeneity and inconsistency was measured using, respectively, Cochran Q tests and $\mathrm{I}^{2}$. Binary outcomes from individual studies were analyzed to compute individual and pooled odds ratios (ORs) with pertinent

TABLE 1. Authors, journals, year of publication, miniaturized CPB device used, and number of patients included in the 16 randomized controlled trials included in this meta-analysis

\begin{tabular}{|c|c|c|c|c|c|c|}
\hline First author & Journal & Year & $\begin{array}{l}\text { Mini CPB device manufacturer } \\
\text { and location }\end{array}$ & Patients & $\begin{array}{l}\text { MECC } \\
\text { patients }\end{array}$ & $\begin{array}{l}\text { Control } \\
\text { patients }\end{array}$ \\
\hline Abdel-Rahman U & Ann Thorac Surg & 2005 & CorX system (Jostra AG, Hirrlingen, Germany) & 204 & 101 & 103 \\
\hline Beghi C & Ann Thorac Surg & 2006 & $\begin{array}{l}\text { Jostra MECC system (CardioVention Inc, Santa } \\
\text { Clara, Calif) }\end{array}$ & 60 & 30 & 30 \\
\hline Castiglioni A & Ann Thorac Surg & 2007 & $\begin{array}{l}\text { Maquet Cardiopulmonary (Jostra AG, Hirrlingen, } \\
\text { Germany) }\end{array}$ & 40 & 17 & 23 \\
\hline Fromes $\mathrm{Y}$ & Eur J Cardiothorac Surg & 2002 & $\begin{array}{l}\text { Jostra MECC system (Jostra AG, Hirrlingen, } \\
\text { Germany) }\end{array}$ & 60 & 30 & 30 \\
\hline Huybregts RA & Ann Thorac Surg & 2007 & $\begin{array}{l}\text { Synergy mini-bypass system (Cobe) (Rastatt, } \\
\text { Germany) }\end{array}$ & 49 & 25 & 24 \\
\hline Kamiya H & Interact Cardiovasc Thorac Surg & 2006 & $\begin{array}{l}\text { Resting Heart System (RHS) (Dideco SrL, } \\
\text { Mirandola, Italy) }\end{array}$ & 20 & 10 & 10 \\
\hline Kutschka I & Interact Cardiovasc Thorac Surg & 2007 & Nonspecified (Jostra, France) & 150 & 75 & 75 \\
\hline Mazzei V & Circulation & 2007 & Jostra MECC system (Tokyo, Japan) & 306 & 150 & 156 \\
\hline Ohata $\mathrm{T}$ & $J$ Artif Organs & 2007 & Capiox, Terumo (Jostra Inc, Hirrlingen, Germany) & 30 & 15 & 15 \\
\hline Prasser C & Perfusion & 2007 & Jostra MECC system (nonspecified) & 20 & 10 & 10 \\
\hline Remadi JP & J Thorac Cardiovasc Surg & 2004 & $\begin{array}{l}\text { Jostra MECC system (CardioVention Inc, Santa } \\
\text { Clara, Calif) }\end{array}$ & 100 & 50 & 50 \\
\hline Remadi JP & Am Heart $J$ & 2006 & Jostra MECC system (Dideco, Mirandola, Italy) & 400 & 200 & 200 \\
\hline Schöttler J & J Thorac Cardiovasc Surg & 2008 & $\begin{array}{l}\text { Maquet Cardiopulmonary (Jostra AG, Hirrlingen, } \\
\text { Germany) }\end{array}$ & 60 & 30 & 30 \\
\hline Skrabal CA & ASAIO $J$ & 2007 & $\begin{array}{l}\text { Maquet Cardiopulmonary (Medtronic, Inc, } \\
\text { Minneapolis, Minn) }\end{array}$ & 60 & 30 & 30 \\
\hline Valtonen M & Scand Cardiovasc J & 2007 & $\begin{array}{l}\text { Extra-Corporeal Circulation Optimized (Hirrlingen, } \\
\text { Germany) }\end{array}$ & 40 & 20 & 20 \\
\hline Wippermann J & Eur J Cardiothorac Surg & 2005 & CorX system (nonspecified) & 20 & 10 & 10 \\
\hline
\end{tabular}

Total patients 1619: MECC 803, control 816. CPB, Cardiopulmonary bypass; Mini CPB, miniaturized cardiopulmonary bypass. 
TABLE 2. Details of interventions and of CPB characteristics in miniaturized cardiopulmonary bypass (mini CPB) or in controls in the 16 randomized controlled trials included in this meta-analysis

\begin{tabular}{|c|c|c|c|c|c|c|c|c|c|}
\hline First author & $\begin{array}{c}\text { Cardiac } \\
\text { surgery } \\
\text { procedures }\end{array}$ & $\begin{array}{c}\text { Priming, } \\
\text { mini } \\
\text { CPB } \\
(\mathrm{mL})\end{array}$ & $\begin{array}{c}\text { Priming, } \\
\text { control } \\
(\mathrm{mL})\end{array}$ & $\begin{array}{c}\text { Circuits, } \\
\text { mini } \\
\text { CPB }\end{array}$ & $\begin{array}{c}\text { Circuits, } \\
\text { control }\end{array}$ & $\begin{array}{c}\text { ACT, } \\
\text { mini } \\
\text { CPB (s) }\end{array}$ & $\begin{array}{c}\text { ACT, } \\
\text { control } \\
(\mathbf{s}) \\
\end{array}$ & $\begin{array}{c}\text { Total } \\
\text { heparin } \\
\text { dose, } \\
\text { mini CPB }\end{array}$ & $\begin{array}{c}\text { Total } \\
\text { heparin } \\
\text { dose, } \\
\text { control }\end{array}$ \\
\hline $\begin{array}{l}\text { Abdel- } \\
\text { Rahman U }\end{array}$ & CABG & 500 & 1750 & Heparin-coated & $\begin{array}{l}\text { Membrane } \\
\text { oxygenator-coated }\end{array}$ & $>400$ & $>400$ & $\begin{array}{l}5000 \mathrm{IU}+ \\
350 \mathrm{IU} / \mathrm{kg}\end{array}$ & $\begin{array}{r}10000 \mathrm{IU}+ \\
350 \mathrm{IU} / \mathrm{kg}\end{array}$ \\
\hline Beghi C & CABG & 450 & 1500 & Heparin-coated & Noncoated & $\mathrm{nr}$ & $\mathrm{nr}$ & $150 \mathrm{IU} / \mathrm{kg}$ & $300 \mathrm{IU} / \mathrm{kg}$ \\
\hline Castiglioni A & $\begin{array}{l}\text { Aortic valve } \\
\text { replacement }\end{array}$ & 500 & 1600 & Heparin-coated & $\begin{array}{l}\text { Coated with } \\
\text { phosphorylcholine }\end{array}$ & $>480$ & $>480$ & $300 \mathrm{IU} / \mathrm{kg}$ & $\begin{array}{l}5000 \mathrm{UI}+ \\
300 \mathrm{IU} / \mathrm{kg}\end{array}$ \\
\hline Fromes Y & CABG & 500 & $\mathrm{nr}$ & Heparin-coated & Heparin-coated & $\mathrm{nr}$ & $\mathrm{nr}$ & $300 \mathrm{UI} / \mathrm{kg}$ & $300 \mathrm{UI} / \mathrm{kg}$ \\
\hline Huybregts RA & CABG & 600 & 1400 & $\begin{array}{l}\text { Phosphorylcholine- } \\
\text { coated }\end{array}$ & $\begin{array}{l}\text { Coated with } \\
\text { phosphorylcholine }\end{array}$ & $480 \mathrm{~s}$ & $480 \mathrm{~s}$ & $400 \mathrm{IU} / \mathrm{kg}$ & $400 \mathrm{IU} / \mathrm{kg}$ \\
\hline Kamiya H & CABG & 900 & 1540 & Heparin-coated & Heparin-coated & $>400$ & $>400$ & $150 \mathrm{U} / \mathrm{kg}$ & $300 \mathrm{U} / \mathrm{kg}$ \\
\hline Kutschka I & $\begin{array}{l}\text { Aortic valve and } \\
\text { aortic root surgery }\end{array}$ & $\mathrm{nr}$ & $\mathrm{nr}$ & $\mathrm{nr}$ & $\mathrm{nr}$ & $\mathrm{nr}$ & $\mathrm{nr}$ & $\mathrm{nr}$ & $\mathrm{nr}$ \\
\hline Mazzei V & CABG & No & No & $\mathrm{nr}$ & No & $\mathrm{nr}$ & $\mathrm{nr}$ & $\mathrm{nr}$ & $\mathrm{nr}$ \\
\hline Ohata T & CABG & 750 & $\mathrm{nr}$ & Heparin-coated & Heparin-coated & $\mathrm{nr}$ & $\mathrm{nr}$ & $300 \mathrm{U} / \mathrm{kg}$ & $300 \mathrm{U} / \mathrm{kg}$ \\
\hline Prasser C & CABG & 550 & 1500 & Heparin-coated & Heparin-coated & $250-300$ & $>400$ & $150 \mathrm{IU} / \mathrm{kg}$ & $375 \mathrm{IU} / \mathrm{kg}$ \\
\hline Remadi JP & $\begin{array}{l}\text { Aortic valve } \\
\text { replacement }\end{array}$ & 450 & 1700 & Heparin-coated & Noncoated & $>400$ & $>400$ & $150 \mathrm{IU} / \mathrm{kg}$ & $300 \mathrm{IU} / \mathrm{kg}$ \\
\hline Remadi JP & CABG & 450 & 1700 & Heparin-coated & Noncoated & 400 & 400 & $300 \mathrm{IU} / \mathrm{kg}$ & $300 \mathrm{IU} / \mathrm{kg}$ \\
\hline Schöttler J & CABG & 900 & 1700 & Heparin-coated & Heparin-coated & $\mathrm{nr}$ & $\mathrm{nr}$ & $5000 \mathrm{IU}+\mathrm{nr}$ & $10000 \mathrm{IU}+\mathrm{nr}$ \\
\hline Skrabal CA & CABG & 500 & 1500 & Heparin-coated & Heparin-coated & 250 & 400 & $\begin{array}{r}200-350 \\
\mathrm{IU} / \mathrm{kg}\end{array}$ & $\begin{array}{r}200-350 \\
\mathrm{IU} / \mathrm{kg}\end{array}$ \\
\hline Valtonen M & CABG & 380 & 2100 & $\begin{array}{l}\text { Phosphorylcholine- } \\
\text { coated }\end{array}$ & $\begin{array}{l}\text { Phosphorylcholine- } \\
\text { coated }\end{array}$ & 480 & 480 & $300 \mathrm{IU} / \mathrm{kg}$ & $300 \mathrm{IU} / \mathrm{kg}$ \\
\hline Wippermann $\mathbf{J}$ & CABG & 820 & 1750 & $\begin{array}{l}\text { Phosphorylcholine- } \\
\text { coated }\end{array}$ & $\begin{array}{l}\text { Phosphorylcholine- } \\
\text { coated }\end{array}$ & 450 & $\mathrm{nr}$ & $400 \mathrm{IU} / \mathrm{kg}$ & $400 \mathrm{IU} / \mathrm{kg}$ \\
\hline
\end{tabular}

$\overline{A C T}$, Activated clotting time; $C A B G$, coronary artery bypass grafting; $C P B$, cardiopulmonary bypass; $n r$, not reported.

$95 \%$ confidence intervals (with equivalence set at $1, \mathrm{OR}<1$ favoring the first treatment, and $\mathrm{OR}>1$ favoring the second treatment), by means of the Peto fixed-effect method in case of low statistical inconsistency $\left(\mathrm{I}^{2} \leq 25 \%\right)$ and by means of a random-effect method (which better accommodates clinical and statistical variations) in case of moderate or high statistical inconsistency $\left(\mathrm{I}^{2}>25 \%\right)$. Weighted mean differences (WMD) and 95\% confidence intervals were computed for continuous variables, again by means of a fixed-effect method in case of low statistical inconsistency $\left(\mathrm{I}^{2} \leq 25 \%\right)$ and by means of a random-effect method in case of moderate or high statistical inconsistency $\left(\mathrm{I}^{2}>25 \%\right){ }^{7}$

The risk of small-study bias (including publication bias, ie, the risk of small, nonsignificant studies being selectively rejected by medical journals) was assessed by visual inspection of funnel plots.

Statistical significance was set at the 2-tailed .05 level for hypothesis testing and at .10 for heterogeneity testing, and unadjusted $P$ values are reported throughout. This study was performed in compliance with The Cochrane Collaboration and the Quality of Reporting of Meta-Analyses (QUOROM) guidelines. ${ }^{8,9}$

\section{RESULTS}

Database searches, snowballing, and contacts with experts yielded a total of 629 citations (Figure 1). Excluding 607 nonpertinent titles or abstracts, we retrieved 22 studies in complete form and assessed them according to the selection criteria. A total of 6 studies were further excluded because of their nonexperimental design, including the use of historical controls, or because of duplicate publication.
Specifically, we excluded 3 studies because of duplicate publication either explicitly acknowledged ${ }^{10}$ or not ${ }^{11,12}: 2$ studies ${ }^{13,14}$ because there were no outcome data and further details could not be obtained by the authors and 1 nonrandomized trial. $^{15}$

We finally identified 16 eligible randomized clinical trials, ${ }^{16-31}$ which were included in the final analysis (Table 1).

\section{Study Characteristics}

The 16 included trials randomized 1619 patients (803 to miniaturized $\mathrm{CPB}$ and 816 undergoing standard cardiac surgery; Table 1). Most studies were performed on patients undergoing on-pump CABG, 1 studied patients having offpump $\mathrm{CABG},{ }^{23}$ and 2 investigated patients having aortic valve replacement. ${ }^{18,26}$ No patients having cardiac reintervention were included. Most authors used the Jostra MECC System. No study was multicentric. In all the studies, cardioplegia was identical in the 2 groups with the exception of the study with the off-pump comparator group and of the only study that was published as an abstract only, ${ }^{22}$ where there was no detail about cardioplegia. All patients were managed with normothermia or mild hypothermia equally in the 2 groups. No cardiotomy suction was used. Details on the 2 study groups are reported in Table 2 . 
TABLE 3. Risk of bias assessment of included studies

\begin{tabular}{|c|c|c|c|c|c|c|c|c|c|}
\hline $\begin{array}{l}\text { Domain/ } \\
\text { question }\end{array}$ & $\begin{array}{c}\text { Adequate } \\
\text { sequence } \\
\text { generation? }\end{array}$ & $\begin{array}{c}\text { Allocation } \\
\text { concealment } \\
\text { used? }\end{array}$ & Blinding? & $\begin{array}{c}\text { Concurrent } \\
\text { therapies } \\
\text { similar? }\end{array}$ & $\begin{array}{c}\text { Incomplete } \\
\text { outcome data } \\
\text { addressed? }\end{array}$ & $\begin{array}{c}\text { Uniform and } \\
\text { explicit } \\
\text { outcome } \\
\text { definitions? }\end{array}$ & $\begin{array}{c}\text { Free of } \\
\text { selective } \\
\text { outcome } \\
\text { reporting? }\end{array}$ & $\begin{array}{c}\text { Free of } \\
\text { other } \\
\text { bias? }\end{array}$ & $\begin{array}{c}\text { Overall } \\
\text { risk } \\
\text { of bias? }\end{array}$ \\
\hline $\begin{array}{l}\text { Abdel-Rahman } \\
\text { et al, } 2005\end{array}$ & Unclear & Unclear & No & Yes & No & No & No & Yes & Moderate \\
\hline Beghi et al, 2006 & Unclear & Yes & No & Yes & No & No & No & Yes & Moderate \\
\hline $\begin{array}{l}\text { Castiglioni et al, } \\
2007\end{array}$ & Unclear & Yes & No & Yes & No & No & No & Yes & Moderate \\
\hline Fromes et al, 2002 & Unclear & Yes & No & Yes & No & No & No & Yes & Moderate \\
\hline $\begin{array}{l}\text { Huybregts et al, } \\
2007\end{array}$ & Unclear & Unclear & No & Yes & No & No & No & Yes & Moderate \\
\hline Kamiya et al, 2006 & Unclear & Unclear & No & Yes & No & No & No & Yes & Moderate \\
\hline $\begin{array}{l}\text { Kutschka et al, } \\
2007\end{array}$ & Unclear & Unclear & No & Yes & No & No & No & Yes & Moderate \\
\hline Mazzei et al, 2007 & Unclear & Unclear & No & Yes & No & No & No & Yes & Moderate \\
\hline Ohata et al, 2007 & Unclear & Unclear & No & Yes & No & No & No & Yes & Moderate \\
\hline Prasser et al, 2007 & $\begin{array}{l}\text { Yes } \\
\text { (computer- } \\
\text { generated } \\
\text { random } \\
\text { numbers) }\end{array}$ & Unclear & No & Yes & No & No & No & Yes & Moderate \\
\hline $\begin{array}{l}\text { Remadi et al, } 2004 \\
\text { (I) }\end{array}$ & Unclear & Unclear & No & Yes & No & No & No & Yes & Moderate \\
\hline $\begin{array}{l}\text { Remadi et al, } 2006 \\
\text { (II) }\end{array}$ & Unclear & Unclear & No & Yes & No & No & No & Yes & Moderate \\
\hline $\begin{array}{l}\text { Schöttler et al, } \\
2008\end{array}$ & Unclear & Unclear & No & Yes & No & No & No & Yes & Moderate \\
\hline Skrabal et al, 2007 & Unclear & Unclear & No & Yes & No & No & No & Yes & Moderate \\
\hline $\begin{array}{l}\text { Valtonen et al, } \\
2007\end{array}$ & Unclear & Unclear & No & Yes & No & No & No & Yes & Moderate \\
\hline $\begin{array}{l}\text { Wippermann et al, } \\
2005\end{array}$ & Unclear & Unclear & No & Yes & No & No & No & Yes & Moderate \\
\hline
\end{tabular}

Study quality appraisal showed that most studies appeared of suboptimal quality, as testified by the common lack of details on the method used for randomized sequence generation and allocation (Table 3).

\section{Quantitative Data Synthesis}

Overall analysis showed that, in comparison with standard cardiac surgery, miniaturized CPB was associated with significant reductions in the rates of the major end points. Specifically, miniaturized CPB reduced the risk of transfusion $(55 / 552[9.9 \%]$ patients were transfused in the miniaturized CPB group vs $101 / 563[17.9 \%]$ in the control arm, OR = $0.42[0.28-0.63], P$ for effect $<.001, P$ for heterogeneity $=$ $.58, \mathrm{I}^{2}=0 \%$; Figure 2$)$, reduced neurologic damage $(4 / 548$ $[0.7 \%]$ vs $19 / 555[3.4 \%]$, OR $=0.30[0.12-0.73], P$ for effect $=.008, P$ for heterogeneity $=.78, \mathrm{I}^{2}=0 \%$; Figure 3 ). Use of miniaturized CPB was also associated with a significant reduction in peak cardiac troponin I release $(\mathrm{ng} / \mathrm{dL}$; WMD $-1.83[-2.47 ;-1.20], P$ for effect $<.001, P$ for heterogeneity $<.001, \mathrm{I}^{2}=97.4 \%$ with 760 included patients; Figure 4) and reduced blood loss $(\mathrm{mL} ; \quad \mathrm{WMD}=-83.20$
[ $-124.46 ;-41.94], P$ for effect $<.0001, P$ for heterogeneity $=.001, \mathrm{I}^{2}=69.1 \%$ with 1083 included patients; Figure 5).

No effect was noted with intensive care unit stay (WMD $=-3.18$ hours $[-6.96 ;-0.61], P$ for effect $=.10, P$ for heterogeneity $<.001, \mathrm{I}^{2}=96.9 \%$ with 1400 included patients), time to hospital discharge (WMD $=-0.11$ days $[-0.42 ;-0.21], P$ for effect $=.50, P$ for heterogeneity $<$ $.33, \mathrm{I}^{2}=13.6 \%$ with 1130 included patients), time on mechanical ventilation (WMD $=-0.49$ hours $[-1.18 ; 0.20], P$ for effect $=.16, P$ for heterogeneity $.33, \mathrm{I}^{2}=12.8 \%$ with 913 included patients), need for inotropic support (82/628 [13.0\%] vs $87 / 642[13.5 \%], \mathrm{OR}=0.91[0.61,1.36], P$ for effect $=.63, P$ for heterogeneity $=.15, \mathrm{I}^{2}=34.6 \%$ with 1270 included patients), atrial fibrillation (89/297 [30\%] vs $104 / 303[34.3 \%]$, OR $=0.83[0.59,1.17], P$ for effect $=.28, P$ for heterogeneity $=.69, \mathrm{I}^{2}=0 \%$ with 600 included patients), low cardiac output syndrome $(5 / 400$ $[1.2 \%]$ vs $13 / 406[3.2 \%], \mathrm{OR}=0.38[0.14,1.08], P$ for effect $=.07, P$ for heterogeneity $=.17, \mathrm{I}^{2}=43.7 \%$ with 806 included patients), intra-aortic balloon pump (3/447 [0.6\%] vs $3 / 459[0.6 \%], \mathrm{OR}=1.03[0.23,4.56], P$ for effect $=.97$, 


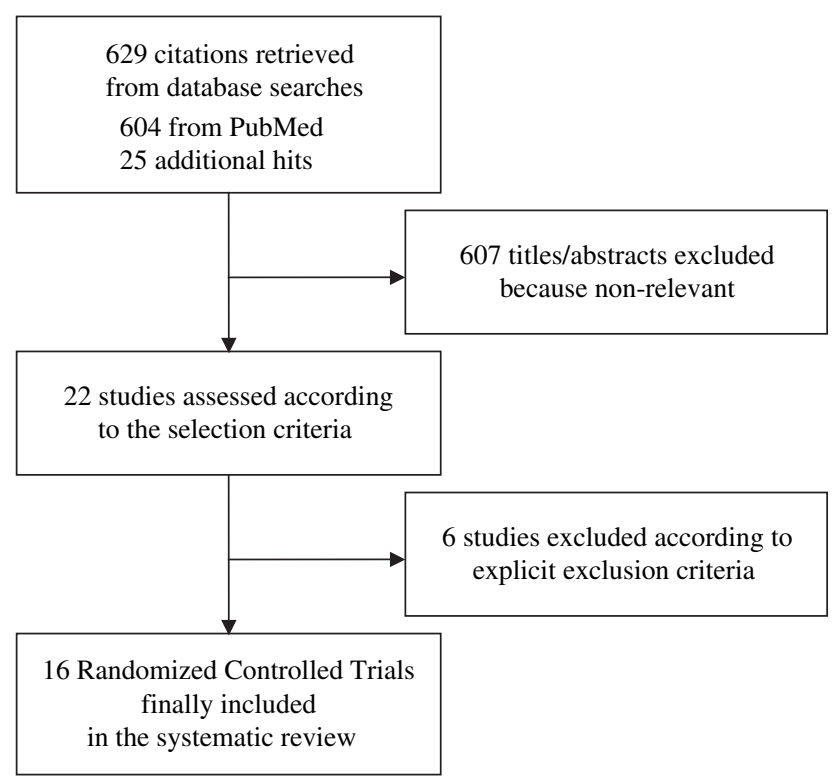

FIGURE 1. Flow diagram of the systematic review process.

$P$ for heterogeneity $=.41, \mathrm{I}^{2}=0 \%$ with 906 included patients), surgical reexploration for bleeding (12/358 [3.3\%] vs $8 / 372[2.1 \%]$, OR $=1.52[0.64,3.59], P$ for effect $=$ $.34, P$ for heterogeneity $=.81, \mathrm{I}^{2}=0 \%$ with 730 included patients), myocardial infarction $(1 / 233[0.4 \%]$ vs $3 / 240$ $[1.25 \%], \mathrm{OR}=0.55[0.12,2.62], P$ for effect $=.45, P$ for heterogeneity $=.43, \mathrm{I}^{2}=0 \%$ with 473 included patients), and mortality $(8 / 758[1.0 \%]$ vs $14 / 771[1.8 \%]$, OR $=$ $0.60[0.26,1.39], P$ for effect $=.23, P$ for heterogeneity $=$ $\left..97, \mathrm{I}^{2}=0 \%\right)$.

We also appraised the robustness and validity of our findings by exploring the likelihood of small-study bias by means of funnel plot inspection, finding no major evidence of such bias. We repeated the analysis excluding the only study where the comparator was off-pump CABG, confirming the results of the major analysis. We also repeated the analysis excluding the Remadi II study ${ }^{27}$ that accounted for 400 of 1619 overall patients and found no differences in the results with exception of the incidence of reduced neurologic damage (3/348 vs $12 / 355, \mathrm{OR}=0.38$ [0.14-1.02], $P$ $=.06$ ), which lost statistical significance.

\section{DISCUSSION}

We performed a meta-analysis of pooled data from several small, underpowered studies and demonstrated that miniaturized CPB significantly decreases blood loss, rate of transfusion, and myocardial and neurologic damage. This technology does not add any benefit in terms of reduction of mortality.

Miniaturized CPB is a new concept of CPB that is based on previous research on reduction of hemodilution, ${ }^{32-36}$ coated systems, ${ }^{37}$ avoidance of cardiotomy suction, ${ }^{38}$ and blood-air contact. ${ }^{39}$ Cardiac surgery and CPB trigger a systemic inflammatory reaction largely caused by the contact of blood with foreign surfaces and by recirculation of activated shed mediastinal blood, which is the main trigger of blood cell activation and cytokine release. ${ }^{40}$ Miniaturized CPB is a closed circuit and involves little or no blood-air contact. It also combines a coating, which may decrease thrombin generation and inflammation, and a low priming volume, which contributes to less hemodilution.

Miniaturized CPB was developed to significantly reduce the hemodilution of the patient and the foreign surface area that comes in contact with the patient's blood. Bloodmaterial interactions are optimized by the use of tip-to-tip coating, centrifugal pumps, and membrane oxygenators; blood-air interaction is avoided by eliminating the venous

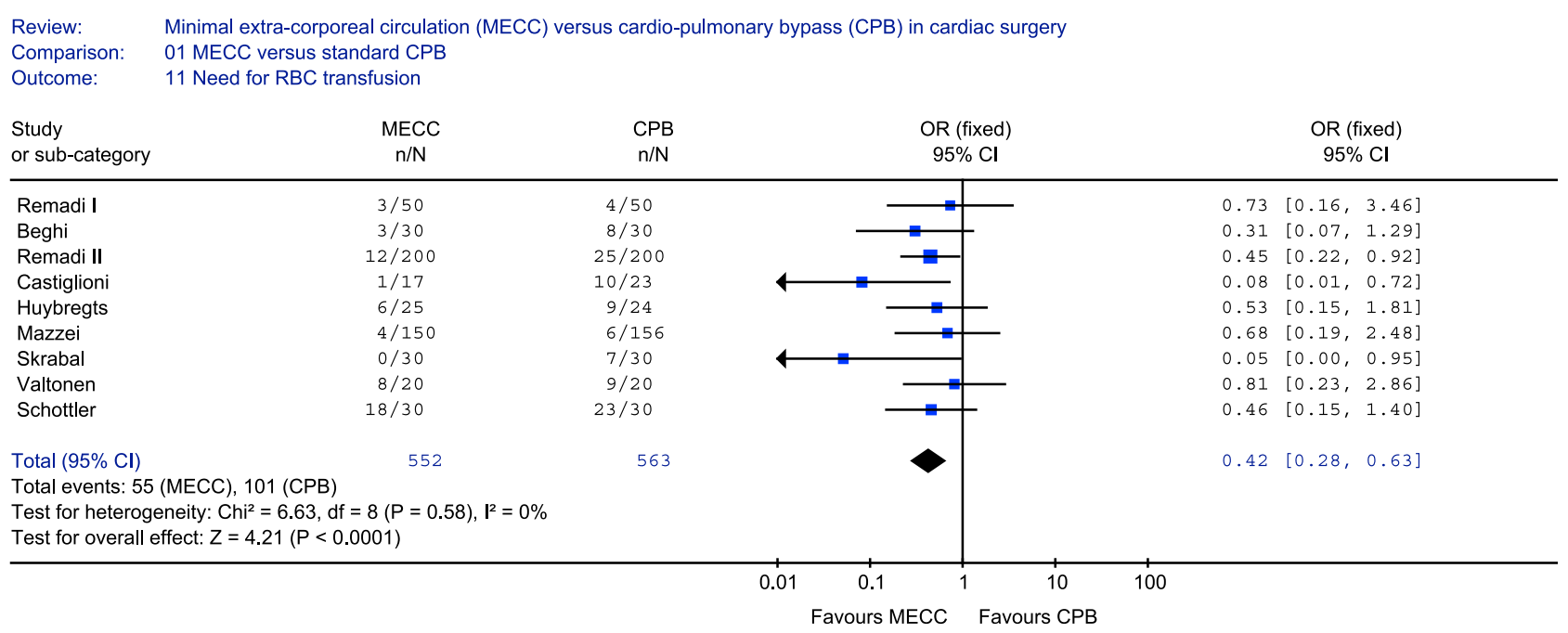

FIGURE 2. Forest plot for the risk of red blood cell transfusions comparing miniaturized cardiopulmonary bypass versus control. $C I$, Confidence intervals; $d f$, degrees of freedom; $O R$, odds ratio pooled estimates of red blood cell transfusions. 


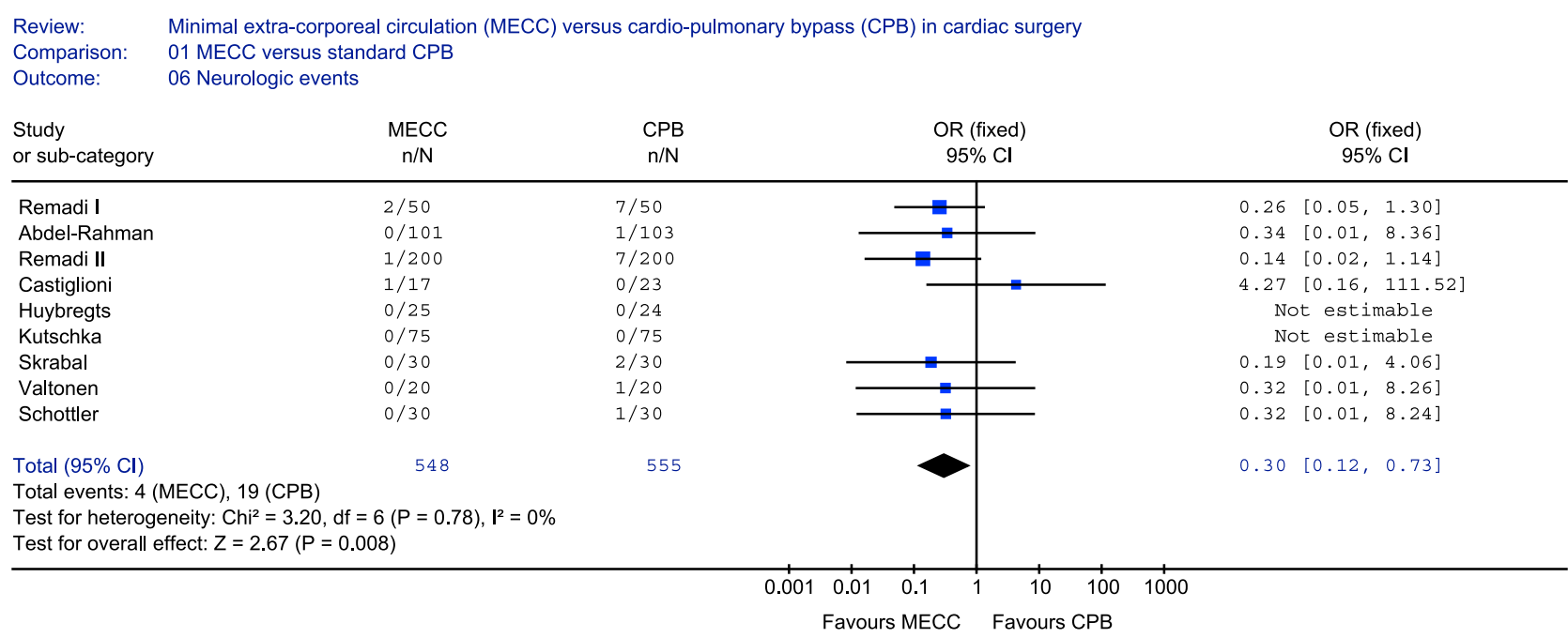

FIGURE 3. Forest plot for the risk of neurologic events comparing miniaturized cardiopulmonary bypass versus control. $C I$, Confidence intervals; $d f$, degrees of freedom; $O R$, odds ratio pooled estimates of neurologic events.

reservoir and cardiotomy suction. Not adding blood from the pericardial wound directly to the perfusion circuit may substantially reduce the amount of circulating thrombin and the severity of the consumptive coagulopathy associated with CPB. Taking these peculiarities into account, the positive results in terms of reduction of postoperative bleeding and need for transfusions are easily explained.

The mechanisms supporting the reduction of myocardial injury with miniaturized CPB in terms of reduction of cardiac troponin release deserve some speculation: it is possible that the unavoidable loss of myocardial cells inherent in aortic crossclamping might be blunted by miniaturized CPB, as a result of reduced production of interleukins and cytokines. This is extremely difficult to determine as probably the most important determinant for the ultimate clinical outcome is the balance between pro- and anti-inflammatory mediators. It is also fair to acknowledge that our meta-analysis failed to show any translation of these data into clinically relevant end point (myocardial infarction, need for inotropic support and intra-aortic balloon pump, low output syndrome).

The data on the better neurologic outcome are strikingly interesting as a major drawback of miniaturized CPB systems (for the lack of venous reservoir and arterial filter) is the potential entrapment of air with the risk of cerebral embolism. Again, these data confirm, in our opinion, that postbypass brain injury is the result of an interplay between micro- and macroemboli, cerebral blood flow, and the inflammatory response. It would actually be unfair to blame standard CPB for inducing neurologic damage; it should be emphasized, however, that the mitigation of the inflammatory response by miniaturized CPB might transfer into relevant clinical outcomes. Indeed, Mazzei and colleagues ${ }^{23}$ claim that miniaturized CPB achieves a degree of brain protection that is comparable to that attributed to off-pump procedures.

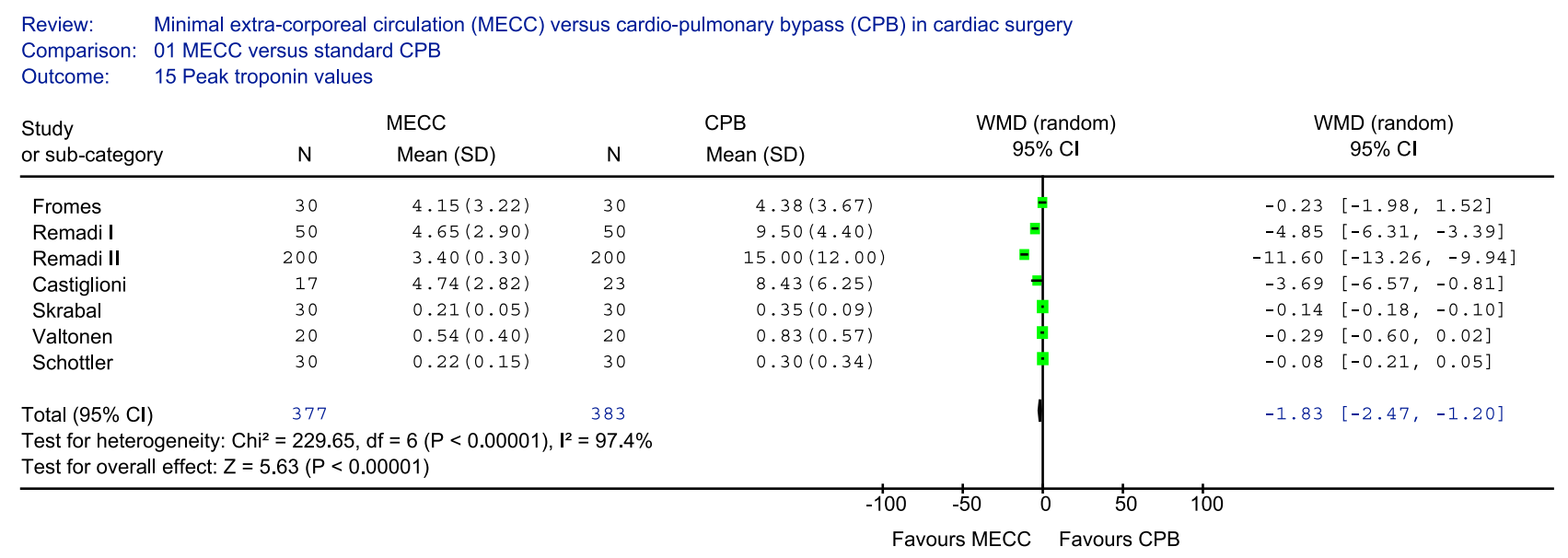

FIGURE 4. Forest plot for postoperative peak troponin release $(\mathrm{ng} / \mathrm{mL})$ comparing mini CPB versus control. $C I$, Confidence intervals; $d f$, degrees of freedom; $O R$, odds ratio pooled estimates of postoperative peak troponin release. 


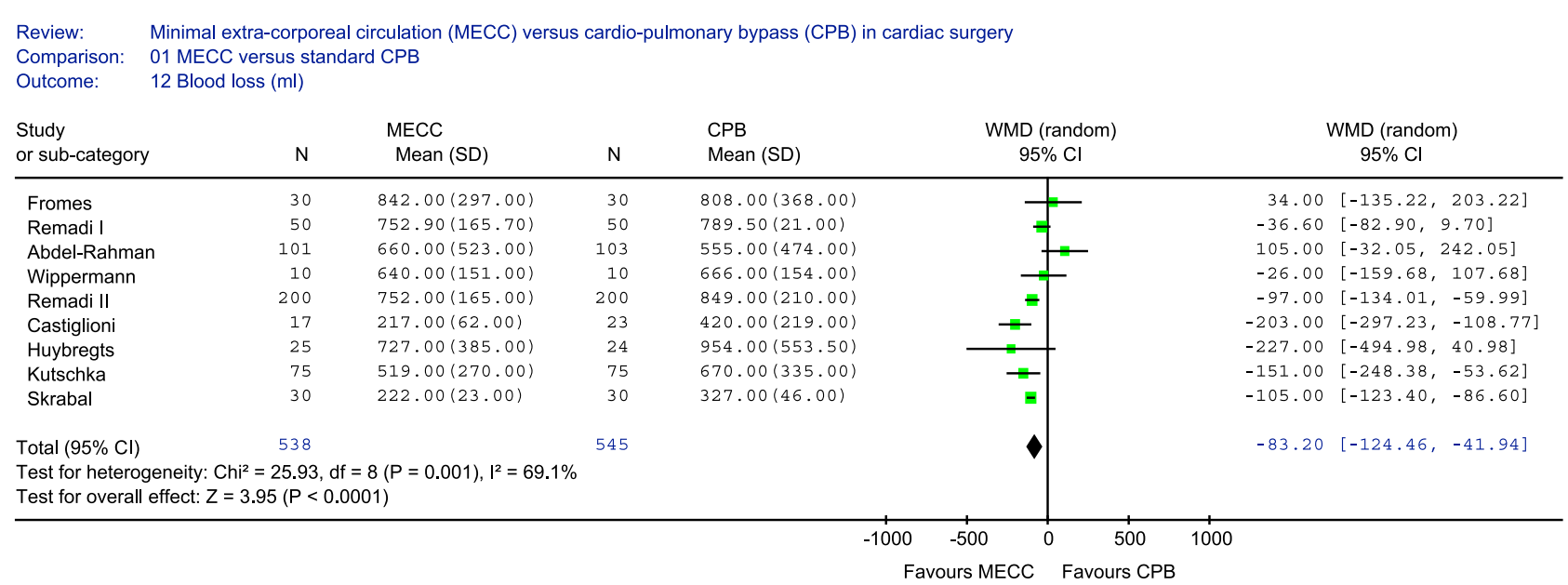

FIGURE 5. Forest plot for blood loss $(\mathrm{mL})$ comparing miniaturized cardiopulmonary bypass versus control. $C I$, Confidence intervals; $d f$, degrees of freedom; $O R$, odds ratio pooled estimates of blood loss mortality.

Negative findings also have to be acknowledged: Schöttler and associates ${ }^{28}$ reported negative hemodynamic effects with more frequent dependence on norepinephrine after operations using miniaturized CPB.

Apart from the operative and in-hospital results, the widespread application of miniaturized CPB systems is jeopardized by the lack of outcome data. The long-term results are too infrequently reported in the current literature to draw definitive conclusions; of particular concern is graft patency, which has already contributed to the disappointing evaluation of offpump CABG, despite the positive findings in the perioperative period. ${ }^{41}$ Mazzei and coworkers ${ }^{23}$ evaluated their study population at 1-year follow-up in terms of mortality, angina recurrence, and need for revascularization: there was a trend in favor of miniaturized $\mathrm{CPB}$ as compared with off-pump $\mathrm{CABG}$, but no statistically significant data.

\section{Limitations}

A critical and balanced review of the literature on miniaturized CPB, through this meta-analysis, does not allow us to draw an unequivocal answer on the role of this technique. This is primarily due to methodologic concerns: small number of high-risk patients, surrogate end points, confounding factors (different miniaturized CPB systems, anticoagulation management, cardioplegia).

An exact comparison of previously published results is difficult because of varying methodologies. Different miniaturized CPB systems and cardioplegic solutions were used. Despite imbalances between treatment strategies among different studies, randomized allocation is maintained by our meta-analysis, limiting the impact of such imbalances. The control group also included 1 off-pump series, ultimately mixing another variable. Even if by far the results of this meta-analysis outweigh the issue of cost and any beneficial effect in term of transfusion injury and cardiac and neurologic damage should be rewarded, we acknowledge that no cost analysis was performed among the included studies. Most study groups received the same CPB coating, whereas others $(n=5)$ had different surface coating. The authors are aware that this is a methodologic limitation; nevertheless, data on surface coating are not so strong enough in standard CPB to jeopardize the results of the present metaanalysis. Furthermore, the total surface area of these circuits was often not reported by the studies included in the metaanalysis.

\section{Conclusions}

Our meta-analysis confirms the potential benefits of different miniaturized CPB systems in comparison to standard cardiac surgery in terms of decreased transfusion rate and cardiac and neurologic damage. The strong interest in miniaturized $\mathrm{CPB}$ might be accounted for the expected reductions in mortality in subgroups of patients who may greatly benefit from miniaturized CPB (patients with severe extracardiac comorbidities, advanced left ventricular dysfunction); new, large randomized controlled trials will clarify this intriguing aspect.

\section{References}

1. Westaby S. Organ dysfunction after cardiopulmonary bypass. A systemic inflammatory reaction initiated by the extracorporeal circuit. Intensive Care Med. 1987; 13:89-95.

2. Ascione R, Lloyd CT, Underwood MJ, et al. Inflammatory response after coronary revascularization with or without cardiopulmonary bypass. Ann Thorac Surg. 2000;69:1198-204.

3. Levy JH, Tanaka KA. Inflammatory response to cardiopulmonary bypass. Ann Thorac Surg. 2003;75:715-20.

4. Mueller XM, Jegger D, Augstburger M, et al. A new concept of integrated cardiopulmonary bypass circuit. Eur J Cardiothorac Surg. 2002;21:840-6.

5. Wiesenack C, Liebold A, Philipp A, et al. Four years' experience with a miniaturized extracorporeal circulation system and its influence on clinical outcome. Artif Organs. 2004;28:1082-8.

6. Biondi-Zoccai GG, Agostoni P, Abbate A, et al. A simple hint to improve Robinson and Dickersin's highly sensitive PubMed search strategy for controlled clinical trials. Int J Epidemiol. 2005;34:224-5. 
7. Higgins JPT, Green S. The Cochrane Handbook for Systematic Reviews of Interventions 4.2.5. Available at: http://www.xmarks.com/site/www.cochrane.dk/ cochrane/handbook/hbook.htm. Accessed August 15, 2009.

8. Moher D, Cook DJ, Eastwood S, et al. Improving the quality of reports of metaanalyses of randomised controlled trials: the QUOROM statement. Quality of Reporting of Meta-analyses. Lancet. 1999;354:1896-900.

9. Biondi-Zoccai GG, Lotrionte M, Abbate A, et al. Compliance with QUOROM and quality of reporting of overlapping metaanalysis on the role of acetylcysteine in the prevention of contrast associated nephropathy: case study. BMJ. 2006;332: 202-9.

10. Abdel-Rahman U, Martens S, Risteski P, Ozaslan F, Riaz M, Moritz A, WimmerGreinecker G. The use of minimized extracorporeal circulation system has a beneficial effect on hemostasis-a randomized clinical study. Heart Surg Forum. 2006;9:543-8.

11. Liebold A, Khosravi A, Westphal B, Skrabal C, Choi YH, Stamm C, et al. Effect of closed minimized cardiopulmonary bypass on cerebral tissue oxygenation and microembolization. J Thorac Cardiovasc Surg. 2006;131:268-76.

12. Skrabal CA, Choi YH, Kaminski A, Steiner M, Kundt G, Steinhoff G, Liebold A. Circulating endothelial cells demonstrate an attenuation of endothelial damage by minimizing the extracorporeal circulation. J Thorac Cardiovasc Surg. 2006;132: 291-6.

13. Immer FF, Ackermann A, Gygax E, Stalder M, Englberger L, Eckstein FS, et al. Minimal extracorporeal circulation is a promising technique for coronary artery bypass grafting. Ann Thorac Surg. 2007;84:1515-20.

14. Immer FF, Pirovino C, Gygax E, Englberger L, Tevaearai H, Carrel TP. Minimal versus conventional cardiopulmonary bypass: assessment of intraoperative myocardial damage in coronary bypass surgery. Eur J Cardiothorac Surg. 2005;28: 701-4.

15. Perthel M, Kseibi S, Sagebiel F, Alken A, Laas J. Comparison of conventional extracorporeal circulation and miminal extracorporeal circulation with respect to microbubbles and microembolic signals. Perfusion. 2005;20:329-33.

16. Abdel-Rahman U, Ozaslan F, Risteski PS, Martens S, Moritz A, Al Daraghmeh A, et al. Initial experience with a minimized extracorporeal bypass system: is there a clinical benefit? Ann Thorac Surg. 2005;80:238-43.

17. Beghi C, Nicolini F, Agostinelli A, Borrello B, Budillon AM, Bacciottini F, et al. Mini-cardiopulmonary bypass system: results of a prospective randomized study. Ann Thorac Surg. 2006;81:1396-400.

18. Castiglioni A, Verzini A, Pappalardo F, Colangelo N, Torracca L, Zangrillo A, Alfieri O. Minimally invasive closed circuit versus standard extracorporeal circulation for aortic valve replacement. Ann Thorac Surg. 2007;83:586-91.

19. Fromes Y, Gaillard D, Ponzio O, Chauffert M, Gerhardt MF, Deleuze P, Bical OM. Reduction of the inflammatory response following coronary bypass grafting with total minimal extracorporeal circulation. Eur $J$ Cardiothorac Surg. 2002;22:527-33.

20. Huybregts RA, Morariu AM, Rakhorst G, Spiegelenberg SR, Romijn HW, de Vroege R, van Oeveren W. Attenuated renal and intestinal injury after use of a mini-cardiopulmonary bypass system. Ann Thorac Surg. 2007;83:1760-6.

21. Kamiya H, Kofidis T, Haverich A, et al. Preliminary experience with the mini-extracorporeal circulation system (Medtronic resting heart system). Interact Cardiovasc Thorac Surg. 2006;5:680-2.

22. Kutschka I, Skorpil J, Schönrock U, et al. Minimised perfusion circuits are beneficial in aortic valve and aortic root surgery. Interact Cardiovasc Thorac Surg. 2007;6: abstract.

23. Mazzei V, Nasso G, Salamone G, et al. Prospective randomized comparison of coronary bypass grafting with minimal extracorporeal circulation system (MECC) versus off-pump coronary surgery. Circulation. 2007;116:1761-7.
24. Ohata T, Mitsuno M, Yamamura M, et al. Minimal cardiopulmonary bypass attenuates neutrophil activation and cytokine release in coronary artery bypass grafting. J Artif Organs. 2007;10:92-5.

25. Prasser C, Abbady M, Keyl C, et al. Effect of a miniaturized extracorporeal circulation (MECC System) on liver function. Perfusion. 2007;22:245-50.

26. Remadi JP, Rakotoarivello Z, Marticho P, et al. Aortic valve replacement with the minimal extracorporeal circulation (Jostra MECC System) versus standard cardiopulmonary bypass: a randomized prospective trial. $J$ Thorac Cardiovasc Surg. 2004;128:436-41.

27. Remadi JP, Rakotoarivelo Z, Marticho $\mathrm{P}$, et al. Prospective randomized study comparing coronary artery bypass grafting with the new mini-extracorporeal circulation Jostra System or with a standard cardiopulmonary bypass. Am Heart J. 2006;151:198.

28. Schöttler J, Lutter G, Böning A, et al. Is there really a clinical benefit of using minimized extracorporeal circulation for coronary artery bypass grafting? Thorac Cardiovasc Surg. 2008;56:65-70.

29. Skrabal CA, Steinhoff G, Liebold A. Minimizing cardiopulmonary bypass attenuates myocardial damage after cardiac surgery. ASAIO J. 2007;53:32-5.

30. Valtonen M, Vähäsilta T, Kaila-Keinänen T, et al. New mini-extracorporeal circulation system (ECC.O) is a safe technique in coronary surgery. Scand Cardiovasc J. 2007; 41:345-50.

31. Wippermann J, Albes JM, Hartrumpf M, et al. Comparison of minimally invasive closed circuit extracorporeal circulation with conventional cardiopulmonary bypass and with off-pump technique in CABG patients: selected parameters of coagulation and inflammatory system. Eur J Cardiothorac Surg. 2005;28:127-32.

32. Karkouti K, Beattie WS, Wijeysundera DN, et al. Hemodilution during cardiopulmonary bypass is an independent risk factor for acute renal failure in adult cardiac surgery. J Thorac Cardiovasc Surg. 2005;129:391-400.

33. Gorman Koch C, Li L, Duncan AI, et al. Morbidity and mortality risk associated with red blood cell and blood-component transfusion in isolated coronary artery bypass grafting. Crit Care Med. 2006;34:1608-16.

34. Habib RH, Zacharias A, Schwann TA, et al. Role of hemodilutional anemia and transfusion during cardiopulmonary bypass in renal injury after coronary revascularization: implications on operative outcome. Crit Care Med. 2005;33:1749-56.

35. Swaminathan M, Phillips-Bute BG, Conlon PJ, et al. The association of lowest hematocrit during cardiopulmonary bypass with acute renal injury after coronary artery bypass grafting. Ann Thorac Surg. 2003;76:784-92.

36. DeFoe GR, Ross CS, Olmstead EM, et al. Lowest hematocrit on bypass and adverse outcomes associated with coronary artery bypass grafting. Ann Thorac Surg. 2001;71:769-76.

37. Pappalardo F, Della Valle P, Crescenzi G, et al. Phosphorylcholine coating may limit thrombin formation during high risk cardiac surgery: a randomized controlled trial. Ann Thorac Surg. 2006;81:886-91.

38. De Somer F, Van Belleghem Y, Caes F, et al. Tissue factor as the main activator of the coagulation system during cardiopulmonary bypass. $J$ Thorac Cardiovasc Surg. 2002;123:951-8.

39. Albes JM, Stohr IM, Kaluza M, et al. Physiological coagulation can be maintained in extracorporeal circulation by means of shed blood separation and coating. $J$ Thorac Cardiovasc Surg. 2003;126:1504-12

40. Menaschè P. The systemic factor: the comparative roles of cardiopulmonary bypass and off-pump surgery in the genesis of patient injury during and following cardiac surgery. Ann Thorac Surg. 2001;72:S2260-6.

41. Bainbridge D, Cheng D, Martin J, et al. Does off-pump or minimally invasive coronary artery bypass reduce mortality, morbidity, and resource utilization when compared with percutaneous coronary intervention? A meta-analysis of randomized trials. J Thorac Cardiovasc Surg. 2007;133:623-31.

\section{APPENDIX}

Search strategy for PubMed, developed according to Biondi-Zoccai et al. (6):

(mecc OR ((minimizing OR minimized OR minimal) AND cardiopulmonary AND bypass) OR ("mini-extracorporeal" AND circulation) OR ("mini-cardiopulmonary" AND bypass AND system) OR (minimally AND invasive AND closed AND circuit) OR (minimal AND extracorpo- real AND circulation) OR ("mini-extracorporeal" AND circulation AND system) OR (medtronic AND resting AND heart AND system) OR (new AND minimized AND perfusion AND circuit) OR (closed AND minimized AND cardiopulmonary AND bypass) OR (minimized AND extracorporeal AND circulation AND system) OR (miniaturized AND extracorporeal AND circulation AND system)) 